\title{
UPAYA MENINGKATKAN MOTIVASI, MINAT DAN HASIL BELAJAR ILMU PENGETAHUAN SOSIAL PADA PESERTA DENGAN MENGGUNAKAN METODE DEMONSTRASI DAN MEDIA GAMBAR
}

\author{
Nama : Idatul Fitri \\ Nim: 836402063 \\ Email : Idatulfitri4@Gmail.Com
}

\begin{abstract}
ABSTRAK
Penelitian Tindakan Kelas ini dilaksanakn di SD Muhammadiyah 01 Depok kelas 1 yang berjumlah 31 peserta didik. Tujuan penelitian ini untuk meningkatkan hasil belajar dan motivasi belajar peserta didik kelas 1 pada mata pelajaran Ilmu Pengetahuan Sosial tentang Peristiwa Penting uang Pernah di Alami dengan menggunakan metode demonstrasi melalui media gambar. Dalam pelaksanaan pembelajaran prasiklus dengan KKM 70 dari jumlah 31 peserta didik diperoleh hasil rerata peserta didik 55,81 dan peserta didik yang mencapai KKM 14 atau $45.16 \%$ Sedangkan mlalui pengamatan peserta didik yang dapat menjawab pertanyaan guru hanya ada 14 (45.16\%). Siklus 1 hasil rerata peserta didik 67,58 yang belum mencapai KKM berjumlah 15 peserta didik atau $48.39 \%$. Melalui data pengamatan peserta didik yang dapat menjawab pertanyaan guru hanya ada 15 (48.39\%) Dalam pelaksanaan pembelajaran siklus 2 diperoleh hasil rerata peserta didik 88,55 peserta didik yang mencapai KKM berjumlah 29 orang atau 93.5\% sedangkan data pengamatan peserta didik yang dapat menjawab pertanyaan guru berjumlah 28 orang peserta didik atau 90.32\%. Penerapan metode demonstrasi melalui Media Gambar telah memberikan pengaruh yang sangat baik dengan meningkatkan hasi belajar dan motivasi peserta didik.
\end{abstract}

Kata-kata kunci: hasil belajar IPA, metode eksperimen . media pembelajaran

\section{PENDAHULUAN}

\section{A. Latar Belakang Belakang Masalah}

Ilmu Pengetahuan Sosial (IPS) merupakan mata pelajaran yang memiliki peranan penting dalam membentuk warga negara yang baik. Ada tiga tujuan membelajarkan IPS kepada peserta didik, yaitu agar setiap peserta didik menjadi warga negara yang baik, melatih peserta didik berkemampuan berpikir matang untuk menghadapi dan memecahkan masalah sosial, dan agar peserta didik dapat mewarisi dan melanjutkan budaya bangsanya.

Untuk itu maka pretasi belajar belajar dan pemahaman peserta didik pada mata pelajaran IPS harus baik, Akan tetapi berdasarkan pengamatan hasil observasi penelitian di SD Muhammadiyah 01 Depok kelas 1 Mata 
Pelajaran IPS tentang "Peristiwa Penting yang Dialami" dengan Kriteria Ketuntasan Maksimum (KKM) 70 diperoleh rata-rata peserta didik 55,81 dengan perincian 14 orang peserta didik dari 31 atau $54.84 \%$ tidak mencapai KKM, dan 17 orang peserta didik atau $45.16 \%$ mencapai KKM.

Kegagalan tersebut disebabkan karena beberapa faktor dan kondisi di lingkungan belajar, baik dari faktor peserta didik, sarana dan prasarana, maupun dari kompetensi guru itu sendiri, dalam menyajikan metode yang lebih berfariasi dalam proses pembelajaran. Sehingga kemampuan guru di tuntut dalam mengelola kelas agar suasana belajar peserta didik selalu aktif dan produktif dengan metode mengajar yang direncanakan. Selain itu guru harus memiliki pemahaman yang baik mengenai materi ke-IPS-an, metode pembelajaran, dan sistem penilaian, serta tujuan-tujuan pembelajaran IPS. Faktor lain rendah nilai peserta didik adalah mata pelajaran IPS juga diasumsikan sebagai pelajaran yang tidak menarik karena hanya bersifat hafalan. Asumsi yang keliru itu bahkan terjadi pada kalangan guru sendiri,

Oleh karena itu untuk memperbaiki hasil belajar peserta didik khususnya pada pelajaran IPS Kelas 1 di SDN Harjamukti 2 perlu adanya Penelitian Tindakan Kelas (PTK) di dalamnya. Berdasarkan latar belakang masalah di atas, peneliti tertarik untuk mengadakan penelitian dengan judul "Meningkatkan Hasil Belajar Ilmu Pengetahuan Sosial Tentang Peristiwa Penting yang Pernah di Alami Pada Peserta Didik Kelas 1 di SD Muhammadiyah 01 Depok dengan Menggunakan Metode Demonstrasi Melalui Media Gambar ”.

\section{Identifikasi Masalah}

Berdasarkan dari latar belakang masalah tersebut, maka dapat di identifikasi masalah sebagai berikut :

a. Rendahnya hasil belajar peserta didik pada mata pelajaran IPS hal ini dilihat dari hasil rerata peserta didik hanya

b. Banyak peserta didik yang sulit memahami materi

c. Peserta didik kurang termotivasi dalam pembelajaran IPS ini dengan materi peristiwa penting yang pernah di alami. 
d. Peserta didik kurang fokus pada saat pembelajaran berlangsung.

e. Peserta didik sangat pasif dalam menerima pelajaran ini.

\section{Analisa Masalah}

Berdasarkan identifikasi masalah di atas maka, di ketahui penyebab dari masalah ini adalah :

a. Guru tidak menggunakan metode pembelajaran dan teknik pembelajaran yang bervariasi dan efektif yang

b. Guru tidak menggunakan media pembelajaran yang sesuai secara maksimal

c. Guru kurang memberikan motivasi pada saat pembelajaran berlangsung sehingga peserta didik tidak tertarik pada pelajaran IPS

d. Guru kurang memberikan kesempatan kepada peserta didik untuk bertanya dan melibatkan peserta didik dalam materi ini.

e. Guru jarang mengadakan dan reward kepada umpan balik secara langsung selama pembelajaran, sehingga peserta didik tidak aktif.

\section{Alternatif dan Prioritas Pemecahan Masalah}

Keberhasilan dari suatu proses pembelajaran untuk memenuhi keinginan dalam peningkatan kualitas di tentukan beberapa faktor, salah satu di antaranya adalah pemilihan media pembelajaran yang tepat untuk menunjang peningkatan minat belajar peserta didik yaitu dengan cara :

a. Guru sebaiknya menggunakan metode pembelajaran dan teknik pembelajaran yang bervariasi dan efektif

b. Guru sebaiknya menggunakan media pembelajaran yang sesuai secara maksimal sehingga terciptanya suasana pembelajaran yang kondusif, dan menyenangkan bagi peserta didik

c. Guru harus memberikan motivasi pada saat pembelajaran berlangsung sehingga peserta didik tertarik pada pelajaran IPS

d. Guru harus memberikan kesempatan kepada peserta didik untuk bertanya dan melibatkan peserta didik dalam materi ini.

e. Guru harus mengadakan reward dan umpan balik secara langsung selama pembelajaran, sehingga peserta didik tidak aktif. 


\section{A. Rumusan Masalah}

Berdasarkan identifikasi dan analisis masalah yang dipaparkan di atas, dapat dirumuskan masalah adalah"bagaiaman meningkatkan hasil belajar ilmu pengetahuan sosial tentang Peristiwa Penting yang Pernah di Alami dengan menggunakan metode demonstrasi dan media gambar pada peserta didik kelas 1 di SD Muhammadiyah 01 Depok

\section{B. Tujuan Penelitian Perbaikan Pembelajaran}

Berdasarkan uraian dari rumusan masalah setiap kegiatan penelitian yang di lakukan adalah untuk meningkatkan hasil belajar Ilmu Pengetahuan Sosial tentang peristiwa penting yang pernah di alami dengan menggunakan metode demonstrasi dan media gambar pada peserta didik kelas 1 di SD Muhammadiyah 01 Depok.

\section{Manfaat Penelitian Perbaikan Pembelajara}

Manfaat penelitian perbaikan pembelajaran di susun dalam rangka peningkatan mutu pendidikan dan memberikan manfaat yang positif bagi berbagai pihak :

1. Bagi peserta didik

a. Dapat memotivasi peserta didik untuk belajar lebih giat khususnya dalam pembelajaran IPS sehingga mengurangi kebosanan dalam belajar.

b. Dapat mengembangkan rasa kebersamaan dan kerja sama peserta didik dengan peserta didik lain.

c. Membiasakan peserta didik berani tampil dan percaya diri.

2. Bagi Guru

a. Memperbaiki pembelajaran yang di kelola.

b. Dapat mengetahui masalah - masalah dan kesulitan yang di hadapi peserta didik dalam pembelajaran IPS.

c. Dapat meningkatkan kualitas pembelajaran. 
3. Bagi sekolah

a. Hasil laporan penelitian ini dapat di gunakan sebagai tambahan referensi bagi rekan guru yang akan mengadakan penelitian.

b. Dapat memberikian perbaikan mutu pelajaran IPS di kelas 1 SDN Harjamukti 2.

4. Untuk Peneliti :

a. Sebagai pengalaman berharga bagi peneliti dalam mengaplikasikan ilmu pengetauan sehingga akan memperkaya khasanah pengetahuan penelitian untuk diamalkan.

b. Sebagai bahan acuan untuk menjadi lebih baik lagi.

\section{KAJIAN PUSTAKA}

\section{A. Hasil Belajar Ilmu Pengetahuan Sosial}

1. Hasil Belajar

Hasil belajar merupakan gabungan dari dua kata yaitu hasil dan belajar Menurut Kamus Besar Bahasa Indonesia hasil adalah sesuatu yang diadakan (dibuat, dijadikan, dan sebagainya) oleh usaha (http://kbbi.web.id). Sedangkan Pengertian belajar menurut Slameto (2003: 2) bahwa belajar ialah "Suatu usaha yang dilakukan seseorang untuk memperoleh suatu perubahan tingkah laku yang baru secara keseluruhan, sebagai hasil pengalamannya sendiri dalam interaksi dengan lingkungannya. Syah, (2004 : 136) menambahkan dalam bukunya Psikologi Belajar bahwa belajar adalah "tahapan perubahan seluruh tingkah laku individu yang relatif menetap sebagai hasil pengalaman dan interaksi dengan lingkungan yang melibatkan proses kognitif".

Selanjutnya menurut Winkel (1990:66), belajar adalah suatu aktifitas mental atau psikis yang berlangsung dalam suatu interaksi aktif dengan lingkungannya, yang menghasilkan perubahan-perubahan pengetahuan, pengalaman, keterampilan dan nilai sikap. Lebih lanjut Gagne (1985) dalam Anitah (2013:1.3) menyatakan belajar adalah suatu 
proses dimana suatu organisme berubah perilakunya sebagai akibat pengalaman. Dari pengertian tersebut terdapat 3 ciri utama yaitu proses, perubahan perilaku atau tingkah laku, dan pengalaman. Lebih lanjut Ernest R. Hilgard dalam Anitah (2013: 2.4) menyampaikan belajar merupakan proses perubahan tingkah laku yang diperoleh melalui latihan. Perubahan ini di sebabkan oleh adanya dukungan dari lingkungan yang positif yang menyebabkan terjadinya interaksi edukatif.

Sedangkan Menurut Abdurrahman (1999) dalam Jihad (2013: 14), hasil belajar merupakan keluaran (outputs) dari suatu sistem pemrosesan masukan (input). Masukan dari sitem tersebut berupa bermacam-macam informasi sedangkan keluarannya adalah perbuatan atau kinerja (performance). Masih

Hasil belajar merupakan kulminasi dari suatu proses yang telah dilakukan dalam belajar. Hasil belajar harus menunjukkan suatu perubahan tingkah laku atau perolehan perilaku yang baru dari siswa yang bersifat menetap, fungsional, positif dan disadari (Anitah, 2009: 2.19). Ada berbagai faktor yang dapat mempengaruhi proses dan hasil belajar siswa di sekolah yang secara garis bessarnya dapat dibagi dalam dua bagian yaitu faktor internal dan faktor eksternal siswa. (Sabri, 1995 : 59). Faktor-faktor yang berasal dari luar diri siswa (eksternal) terdiri dari faktor lingkungan dan faktor instrumental. Sedangkan faktor-faktor yang berasal dari dalam diri siswa (internal); adalah berupa faktor fisiologis dan psikologis pada diri siswa.

Melalui uraian para ahli di atas dapat dikatakan bahwa hasil belajar merupakan keluaran (outputs) yang diperoleh pada titik puncak kulminasi dari proses belajar mengajar. Dalam proses belajar ini di dalamnya terdapat proses pemasukan berupa informasi. Outputs yang diperoleh berupa perubahan tingkah laku atau perilaku yang baru yang bersifat positif dan disadari. Kualitas hasil belajar dapat dilihat dari hasil pengukuran berupa evaluasi 


\section{Hakikat Ilmu Pengetahuan Sosial}

Istilah Ilmu Pengetahuan Sosial, disingkat IPS, menurut Supriya (2009:19) merupakan nama mata pelajaran di tingkat sekolah dasar dan menengah atau nama program studi di perguruan tinggi identik dengan istilah "social studies". Pemikiran mengenai konsep Ilmu Pengetahuan Sosial di Indonesia banyak dipengaruhi oleh pemikiran "sosial studies" di Amerika Serikat. Pilar historis-epistemologis, "Sosial Studies" pertama kali disampaikan oleh Edgar Bruce Wesley bahwa studi sosial adalah ilmu-ilmu yang disederhanakan untuk tujuan pendidikan (Barr, Bart dan Shermis, 1977: 1-2 dalam Winaputra 2010: 1.3).

Konsep IPS masuk ke dalam dunia pendidikan di Indonesia pada tahun 1972 - 1973, yakni dalam kurikulum IPS di Indonesia, jenjang pendidikan SD dan SMP, pendidikan IPS dilakukan secara terpadu, sementara pada jenjang SMA, pendidikan IPS sudah mulai di partisi menjadi beberapa bidang kajian, yaitu sejarah, ekonomi, sosiologi dan geografi. Pada kurikulum 1994 ditambah dengan bidang kajian tata negara dan antropologi. (Wahab, 2008: 2.19).

Kurikulum IPS tahun 2006 bertujuan agar peserta didik memiliki kemampuan sebagai berikut .

1) Mengenal konsep-konsep yang berkaitan dengan kehidupan masyarakat dan lingkungan.

2) Memiliki kemampuan dasar untuk berpikir logis dan kritis, rasa ingin tahu, memecahkan masalah, dan keterampilan dalam kehidupan sosial.

3) Memiliki komitmen dan kesadaran terhadap nilai-nilai sosial dan kemanusiaan.

4) Memiliki kemampuan berkomunikasi, bekerja sama dan berkompetisi dalam masyarakat yan majemuk, di tingkat lokal, nasional, dan global (Sardiyo, 2009:1.26).

Ahmadi (2009 : 3) menjelaskan bahwa Ilmu Pengetahuan Sosial adalah ilmu-ilmu sosial yang dipilih dan disesuaikan bagi program pendidikan di sekolah atau bagi kelompok belajar yang sederajat. Menurut 
Puskur (2001:9) IPS adalah suatu bahan kajian terpadu yang merupakan penyederhanaan, adaptasi, seleksi dan modifikasi diorganisasikan dari konsep-konsep ketrampilan-ketrampilan Sejarah, Geografi, Sosiologi, Antropologi, dan Ekonomi. Istilah IPS di sekolah dasar merupakan nama mata pelajaran yang berdiri sendiri sebagai integrasi dari sejumlah konsep disiplin ilmu sosial, humaniora, sains bahkan berbagai isu dan masalah sosial kehidupan

Berdasarkan pengertian hasil belajar IPS, disimpulkan bahwa hasil belajar adalah kemampuan-kemampuan yang dimiliki peserta didik setelah menerima pengalaman belajarnya dalam penyederhanaan, adaptasi, seleksi dan modifikasi diorganisasikan dari konsep-konsep ketrampilanketrampilan Sejarah, Geografi, Sosiologi, Antropologi, dan Ekonomi. kemampuan-kemampuan tersebut mencakup aspek kognitif, afektif, dan psikomotorik.

\section{B. Metode Demonstrasi}

Menurut Syah (2000:22) metode demonstrasi adalah metode mengajar dengan cara memperagakan barang, kejadian, aturan, dan urutan melakukan suatu kegiatan baik secara langsung maupun melalui penggunaan media pengajaran yang relevan dengan pokok bahasan atau materi yang sedang disajikan.

Menurut Djamarah, (2000:2) metode demonstrasi adalah metode yang digunakan untuk memperlihatkan sesuatu proses atau cara kerja suatu benda yang berkenaan dengan bahan bahan pelajaran. Selanjutnya menurut Sagala, (2008:210) metode demonstrasi ini lebih sesuai untuk mengajarkan pelajaran yang merupakan suatu proses maupun hal-hal yang bersifat rutin. Dengan metode demonstrasi peserta didik berkesempatan mengembangkan kemampuan mengamati segala benda yang sedang terlibat dalam proses pembelajaran serta dapat mengambil kesimpulan-kesimpulan yang diharapkan. 
Menurut Anitah (2013:5.25) menjelaskan bahwa metode demonstrasi semata-mata digunakan hanya untuk :

1. Mengkongkritkan suatu konsep atau prosedur yang abstrak.

2. Mengajarkan bagaimana berbuat atau menggunakan prosedur secara tepat.

3. Meyakinkan bahwa alat dan prosedur tersebut bisa digunakan.

4. Membangkitkan minat menggunakan alat prosedur.

Manfaat psikologis metode demonstrasi adalah :

1. Perhatian siswa dapat lebih dipusatkan.

2. Proses belajar siswa lebih terarah pada materi yang sedang dipelajari.

3. Pengalaman dan kesan sebagai hasil pembelajaran lebih melekat pada dirisiswa.

Menggunakan metode demonstrasi memiliki keunggulan sebagai berikut

1. Perhatian siswa dapat dipusatkan pada hal-hal yang dianggap penting oleh guru sehingga yang penting itu dapat diamati secara teliti.

2. Siswa dapat memehami bahan pelajaran sesuai dengan objek yang sebenarnya

3. Dapat mengembangkan rasa ingin tahu siswa.

4. Dapat melakukan pekerjaan berdasarkan proses yang sistimatis.

5. Ekonomis dalam jam pelajaran di sekolah dan ekonomi dalam waktu yang panjang dapat diperlihatkan melalui demonstrasi dengan waktu yang pendek.

6. Dapat mengurangi kesalahan-kesalahan bila dibandingkan dengan hanya membaca atau mendengarkan, karena murid mendapatkan gambaran yang jelas dari hasil pengamatannya.

7. Beberapa persoalan yang menimbulkan pertanyaan atau keraguan dapat diperjelas waktu proses demonstrasi.

Kelemahan metode demonstrasi dari meteode ini adalah

1. Sering terjadi siswa kurang berani dalam mencoba atau Hanya dapat menimbulkan cara berfikir yang kongkrit saja. 
2. Jika jumlah siswa banyak dan posisi siswa tidak diatur maka demonstrasi tidak efektif.

3. Bergantung pada alat bantu yang sebenarnya.

4. melakukan praktik yang didemonstrasikan .

5. Tidak semua hal dapat didemonstrasikan di kelas. (Anitah, 2009:5.25).

Jadi dari berbagai penjelasan di atas dapat disimpulkan bahwa Metode Demonstrasi merupakan metode mengajar yang menyajikan bahan pelajaran dengan mempertunjukkan secara langsung objek atau cara melakukan sesuatu sehingga dapat mempelajarinya dengan proses

\section{Media Gambar}

Media adalah perantara atau pengantar pesan dari pengirim sumber pesan kepada penerima pesan secara terminologi yang telah memperluas kemampuan manuasia untuk merasakan atau mendengar. Menurut Hamalik (2013:114) media adalah alat,metode dan teknik yang digunakan dalam rangka mengaktifkan komunikasi dan interaksi guru dan peserta didik dalam proses pembelajaran. Bahwa media pembelajaran merupakan sarana atau bentuk komunikasi yang merupakan wadah informasi.

Ada beberapa macam media pembelajaran antara lain:

1. Media visual yang tidak diproyeksikan ( gambar, ilustrasi, karikatur, poster, bagan, diagram, grafik dan peta )

2. Media audio ( wawancara, berita, radiao, warta berita, drama radio

3. diskusi dan seminar).

4. Media visual yang diproyeksikan ( Over Head, Projector, slide proyektor)

5. Media cetak ( buku pelajaran, modul, majalah, surat kabar ).

Selanjutya Hamalik (201:43) berpendapat bahwa gambar adalah segala sesuatu yang diwujudkan secara visual dalam bentuk dua dimensi sebagai curahan perasaan atau pikiran. Sedangkan menurut Sumantri, (2006:178) mengemukakan bahwa secara umum media gambar berfungsi sebagai: 
1. Alat bantu untuk mewujudkan situasi belajar mengajar yang efektif.

2. Bagian integral dari keseluruhan situasi mengajar.

3. Meletakkan dasar-dasar konkret yang abstrak sehingga dapat mengurangi pemahaman yang besifat verbalisme

4. Mengembangkan motivasi belajar peserta didik

5. Mempertinggi mutu belajar mengajar.

Dari definisi diatas secara khusus media gambar berfungsi untuk menarik perhatian para peserta didik dalam pembelajaran dikelas. Pada penelitian ini penulis menggunakan dua metode gambar dan media gambar

\section{Penelitian Tindakan Kelas (PTK)}

Menurut Arikunto (2012:3) mengemukakan Penelitian Tindakan Kelas merupakan suatu pencermatan terhadap kegiatan belajar berupa sebuah tindakan yang sengaja dimunculkan dan terjadi dalam sebuah kelas yang bersamaan. Lebih lanjut menurut Asrori (2009:6) Penelitian Tindakan Kelas didefinisikan sebagai suatu bentuk yang bersifat reflektif dengan sehngga dapat hasil belajar yang lebih baik.

Wardani (2014:1.4) menjelaskan bahwa Penelitian Tindakan Kelas adalah penelitian yang dilakukan oleg guru di dalam kelasnya sendiri melalui refleksi diri dengan tujuan untuk memperbaiki kinerja sebagai guru sehingga hasil belajar siswa menjadi meningkat.

Menurut Arikunto (2012:17) secara garis besar ada 4 tahap langkahlangkah dalam Penelitian Tindakan Kelas yaitu :

1. Menyusun Rencana Tindakan (planning)

2. Pelaksanaan Tindakan (action)

3. Pengamatan (observing)

4. Refleksi (reflecting)

Langkah-langkah Penelitian Tindakan Kelas sebagai berikut :

1. Melakukan identifikasi masalah.

2. Melakukan analisa masalah dan perumusan masalah.

3. Merumuskan hipotesis tindakan sebagai alternative pemecahan masalah. 
4. Analisis kelayakan pemecahan masalah. Asrori (2009:61)

Manfaat penelitian tindakan kelas dapat dilihat dan dikaji dalam beberapa komponen pendidikan dan pembelajaran di kelas, diantaranya :

1. Inovasi pembelajaran.

2. Pengembangan kurikulum.

3. Peningkatan profesionalisme pendidikan. Supardi (2012:108)

Dari beberapa pengertian di atas dapat disimpulkan bahwa penelitian melakukan tindakan-tindakan tertentu untuk memperbaiki dan meningkatkan praktik pembelajaran di kelas secara lebih berkualitas

\section{PELAKSANAAN PENELITIAN PERBAIKAN PEMBELAJARAN}

\section{A. Subjek, Tempat, Waktu Penelitian dan Pihak yang Membantu}

\section{Subjek dan Tempat Penelitian}

Subjek penelitian adalah peserta didik kelas 1 yang berjumlah 31 Peserta didik terdiri dari sebagai 12 Laki- laki dan 19 Perempuan pada mata pelajaran IPS tentang "Peristiwa Penting yang di Alami" Tempat penelitian ini dilakukan di SDN Harjamukti 2 di jalan Pringgondani RT 03 RW 09 Kelurahan Harjamukti Kecamatan Cimanggis Kota Depok.

\section{Waktu Penelitian}

Penelitian ini dilaksanakan mulai hari Kamis tanggal, 14 Juni 2019 diawali dengan prasiklus yang menjadi sumber masalah yang ditemukan, perbaikan pembelajaran siklus I pada hari Selasa tanggal, 19 Juni 2019. Selanjutnya perbaikan pembelajaran siklus 2 pada hari Kamis, tanggal 21 Juni 2019.

\section{Pihak yang Membantu Penelitian}

1. Nentih S.Pd. sebagai supervisor 2

2. Tuti Suparyanti, M.Pd. selaku Kepala Sekolah SD Negeri Harjamukti 2.

\section{B. Desain Prosedur Perbaikan Pembelajaran}


Dalam Penelitian ini dilaksanakan dua siklus yang masing-masing melalui 4 tahapan yaitu tahap perencanaan, pelaksanaan, pengamatan dan refleksi. Adapun pelaksanaan penelitian tersebut dideskripsikan sebagai berikut:

\section{Prasiklus}

\section{a. Persiapan}

a) Perencanaan pelaksanaan pembelajaran yang akan dilaksanakan pada hari Kamis, tanggal 14 Juni 2019

b) Penyusunan Rencana Pembelajaran IPS dengan Tema Peristiwa Penting yang di Alami

c) Penyusunan metode pembelajaran berupa ceramah dan tanya jawab.

d) Persiapan sumber belajar dan bahan ajar.

e) Penyusunan alat evaluasi pembelajaran.

\section{b. Pelaksanaan}

1) Kegiatan awal (10 menit)

1. Guru mengajak peserta didik berdoa, mengisi daftar kelas, menulis hari dan tanggal di papan tulis dan mempersiapkan materi ajar.

2. Guru memperingatkan peserta didik cara duduk yang baik ketika menulis, membaca dan meluruskan barisan meja dan kursi mereka

3. Guru memberikan motivasi belajar kepada para peserta didik melalui "tepuk semangat".

4. Guru menyampaikan tujuan pembelajaran hari ini.

2) Kegiatan inti (40 menit)

1. Guru menjelaskan materi 'Peristiwa yang Pernah di Alami"

2. Guru menuliskan dan menjelaskan contoh peristiwa yang pernah di alami

3. Tanya jawab tentang hal yang belum diketahui peserta didik.

3). Kegiatan Akhir (20 menit) 
1. Guru memberikan tugas berupa LKS terkait materi yang baru saja dipelajari.

2. Peserta didik mengerjakan tugas yang diberikan guru.

3. Guru memberian PR / tugas

4. Menutup pelajaran

\section{c. Pengamatan}

Berdasarkan hasil pengamatan saat proses pembelajaran berlangsung, ditemukan beberapa permasalahan, yaitu:

1. Kegiatan pembelajaran yang berlangsung tidak menarik sehingga peserta didik merasa jenuh akibat guru hanya menggunakan metode ceramah dan tanya jawab.

2. Peserta didik tidak aktif, karena kurang dilibatkan oleh guru.

3. Guru tidak menggunakan media pembelajaran.

4. Guru kurang memotivasi peserta didik terhadap keberhasilan peserta didik.

5. Nilai rerata hasil evaluasi masih jauh di bawah $\operatorname{KKM}(70,00)$

\section{d. Refleksi}

Setelah dilakukan evaluasi, ternyata pemilihan metode yang kurang tepat menjadi faktor penyebabnya. Guru hanya menggunakan metode ceramah, sehingga tidak ada peserta didik terlibat aktif selama proses pembelajaran berlangsung. Hal ini menyebabkan para peserta didik merasa jenuh dan kurang termotivasi untuk mengikuti proses pembelajaran. Untuk mengatasi permasalahan tersebut maka peneliti perlu menambahkan metode pembelajaran yang ada dengan yang lebih banyak melibatkan dan menarik minat peserta didik.

Dari hasil belajar peserta didik yang jumlah 31 diperoleh hasil rerata peserta didik 55,81 dan hanya 14 orang peserta didik mencapai KKM atau 45.16\%. Sedangkan melalui melalui pengamatan guru peserta didik yang dapat menjawab pertanyaan guru hanya ada 14 peserta didik, atau sebesar $45.16 \%$. 


\section{Siklus 1}

\section{a. Persiapan}

1. Perencanaan pelaksanaan pembelajaran yang akan dilaksanakan pada hari, Selasa, tanggal 19 Juni 201914.

2. Guru menyusunan Rencana Pembelajaran IPS dengan Tema Peristiwa Penting yang di Alami

3. Penyusunan metode pembelajaran berupa ceramah dan tanya jawab.

4. Persiapan sumber belajar dan bahan ajar.

5. Penyusunan alat evaluasi pembelajaran atau lembar kerja peserta didik (LKS)

\section{b. Pelaksanaan}

1) Kegiatan awal (10 menit)

a) Guru mengajak peserta didik berdoa, mengisi daftar kelas, menulis hari dan tanggal di papan tulis dan mempersiapkan materi ajar.

b) Guru memperingatkan peserta didik cara duduk yang baik ketika menulis, membaca dan meluruskan barisan meja dan kursi mereka

c) Guru memberikan motivasi belajar kepada para peserta didik melalui "tepuk semangat" dan menyanyikan Pada Hari Minggu"

d) Guru memperlihatkan contoh peristiwa penting yang pernah dialami diikuti tanya jawab

e) Guru menyampaikan tujuan pembelajaran setelah pembelajaran peserta didik dapat menyebutkan peristiwa yang pernah di alami

f) Guru menyampaikan topik yang akan dipelajari yaitu "Peristiwa Penting yang di Alami"

g) Guru mengaitkan tofik dengan menyampaikan manfaat konsep tersebut dalam kehidupan sehari-hari 
2) Kegiatan inti (40 menit)

a) Guru menyebutkan beberapa Peristiwa Penting yang di Alami

b) Guru meminta peserta didik memperhatikan gambar Peristiwa Penting yang di Alami

c) Guru menjelaskan kejadian yang telah terjadi peristiwa ada yang penting ada yang biasa saja ada yang masih kita ingat ada pula yang sudah kita lupa.

d) Peserta didik dimita menyebutkan dan Peristiwa penting yang alami di rumah dan di lingkungan sekitar atau sekolah

e) Guru meminta beberapa peserta didik untuk maju kedepan menyebutkan peristiwa penting yang alami di rumah dan di lingkungan sekitar atau sekolah

f) Guru memberikan kesempatan peserta didik untuk bertanya

3). Kegiatan Akhir (20 menit)

a) Guru bersama peserta didik menyimpulkan pembelajaran

b) Guru memberikan tugas berupa LKS terkait materi yang baru saja dipelajari.

c) Peserta didik mengerjakan tugas yang diberikan guru.

d) Guru memberian PR / tugas

e) Menutup pelajaran

\section{c. Pengamatan}

Berdasarkan pengamatan dan observasi saat guru mengajar, yang menjadi permasalahan dalam pembelajaran tersebut adalah:

a) Peserta didik kurang termotivasi dalam pembelajaran.

b) Nilai rata-rata kelas yang diperoleh 67,58 masih dibawah KKM yaitu 70,00, dan peserta didik yang dapat menjawab pertanyaan hanya 15 dari 31 peserta didik.

c) Tanggung jawab peserta didik akan tugas masih rendah, saat diberikan tugas belum dilaksanakan dengan optimal. 
d) Keterlibatan peserta didik dalam kegiatan pembelajaran masih kurang.

\section{d. Refleksi}

Dari pelaksanaan pembelajaran siklus I, ditemukan kekuatan dan kelemahan dalam tindakan perbaikan pembelajaran diantaranya:

1. Kekuatan
a) Pembelajaran lebih efektif dengan metode .
b) Guru sudah melibatkan peserta didik dalam pembelajaran
c) Peserta didik mulai antusias terhadap media yang digunakan
d) Pemahaman materi oleh peserta didik sedikit lebih baik.

2. Kelemahan
a) Guru kurang memandu siswa
b) Aktiftas peserta didik belum semua terlibat
c) Belum semua peserta didik melakukan mengerti dengan tugasnya
d) Pembelajarn masih didominasi peserta didik yang aktif saja.
e) Perolehan hasil rata-rata kelas masih dibawah KKM yaitu diperoleh 67,58 masih dibawah KKM yaitu 70,00, dan peserta didik yang dapat menjawab pertanyaan hanya 15 dari 31 peserta didik. sehingga perlu dilanjutkan ke siklus berikutnya yaitu siklus II.

\section{Siklus 2}

\section{a. Persiapan}

1) Perencanaan pelaksanaan pembelajaran yang akan dilaksanakan pada hari Kamis, tanggal 21 Juni 2019

2) Pada pertemuan sebelumnya guru menugaskan peserta didik untuk membawa foto keluarga, foto copi akte kelahiran, piagam, mainan waktu kecil, dan rapor Taman Kanak-Kanak

3) Guru menyusunan Rencana Pembelajaran IPS dengan Tema Peristiwa Penting yang di Alami 
4) Penyusunan metode pembelajaran berupa ceramah dan tanya jawab.

5) Persiapan sumber belajar dan bahan ajar.

6) Penyusunan alat evaluasi pembelajaran atau lembar kerja peserta didik (LKS)

\section{b. Pelaksanaan}

1) Kegiatan awal (10 menit)

a) Guru mengajak peserta didik berdoa, mengisi daftar kelas, menulis hari dan tanggal di papan tulis dan mempersiapkan materi ajar.

b) Guru memperingatkan peserta didik cara duduk yang baik ketika menulis, membaca dan meluruskan barisan meja dan kursi mereka

c) Guru memberikan motivasi belajar kepada para peserta didik melalui "tepuk semangat" dan menyanyikan lagu "Pada Hari Minggu"

d) Guru memperlihatkan contoh peristiwa penting yang pernah dialami diikuti tanya jawab untuk mengetahui kemampuan awal peserta didik tentang apa yang akan dipelajari

e) Guru menyampaikan tujuan pembelajaran setelah pembelajaran peserta didik dapat menyebutkan peristiwa yang pernah di alami

f) Guru menyampaikan topik yang akan dipelajari yaitu "Peristiwa Penting yang di Alami"

g) Guru mengaitkan tofik dengan menyampaikan manfaat konsep tersebut dalam kehidupan sehari-hari

2) Kegiatan inti (40 menit)

a) Guru menyebutkan beberapa Peristiwa Penting yang di Alami

b) Guru menjelaskan kejadian yang telah terjadi peristiwa ada yang penting ada yang biasa saja ada yang masih kita ingat 
ada pula yang sudah kita lupa dengan perlihat gambar beberapa peristiwa penting

c) Guru meminta peserta didik memperhatikan gambar Peristiwa Penting yang di Alami

d) Peserta didik diminta menyebutkan dan Peristiwa penting yang alami di rumah dan di lingkungan sekitar atau sekolah dengan media yang mereka bawa

e) Guru meminta beberapa peserta didik untuk maju kedepan menyebutkan peristiwa penting yang alami di rumah dan di lingkungan sekitar atau sekolah dengan media yang mereka bawa

f) Guru memberikan penguatan kepada peserta didik

g) Guru memberikan kesempatan peserta didik untuk bertanya

3). Kegiatan Akhir (20 menit)

a) Guru bersama peserta didik menyimpulkan pembelajaran

b) Guru memberikan tugas berupa LKS terkait materi yang baru saja dipelajari.

c) Peserta didik mengerjakan tugas yang diberikan guru.

d) Guru memberian PR / tugas

e) Menutup pelajaran

\section{c. Pengamatan}

Peneliti melakukan pengamatan terhadap aktivitas peserta didik dalam mengikuti perbaikan pembelajaran dengan metode demonstrasi. Hasil pengamatan ternyata ada perubahan yang sangat berbeda karena peserta didik menjadi aktif, antusias, dan mengerti dengan jelas materi yang dipelajari. Hal itu berpengaruh dari hasil belajar yang meningkat dari Siklus I (nilai rerata 67,58) ke Siklus II (nilai rerata 88,55). Hal ini dikarena 
a. Guru sudah menggunakan media pembelajaran yang sesuai secara maksimal sehingga tidak terciptanya suasana pembelajaran yang kondusif, dan menyenangkan bagi peserta didik

b. Guru sudah menggunakan metode pembelajaran dan teknik pembelajaran yang bervariasi dan efektif

c. Guru sudah memberikan motivasi pada saat pembelajaran berlangsung sehingga peserta didik tidak tertarik pada pelajaran IPS

d. Guru sudah mengadakan reward dan umpan balik secara langsung selama pembelajaran, sehingga peserta didik tidak aktif

\section{d. Refleksi}

Dalam melakukan refleksi perbaikan pembelajaran, penulis dan teman sejawat mencatat beberapa hal yang sangat berpengaruh pada penerapan metode demonstrasi melalui media gambar yaitu:

1) Dengan menggunakan metode demonstrasi, peserta didik mendapatkan suasan baru, sehingga dapat menghindari kebosanan dalam proses pembelajaran.

2) Dengan metode demonstrasi, dapat membiasakan peserta didik untuk berkomunikasi aktif dalam bertukar fikiran dengan teman.

3) metode demonstrasi, peserta didik diajarkan untuk mandiri, dan memiliki rasa setia kawan yang tinggi.

4) Dengan metode demonstrasi pada perbaikan pembelajaran pada siklus II ini hasil nila rerata peserta didik sebesar 88,55 dan 28 daris 31 peserta didik (93.5\%)) yang mendapat nilai di atas KKM. Sedangkan Hasil pengamatan didapat data peserta didik yang dapat menjawab pertanyaan guru dengan benar sebanyak 28dari 31 peserta didik atau sebesar $(90.32 \%)$

5) Dengan metode demonstrasi mendapatkan keuntungan, menambah pengalaman dan kepercayaan diri, peserta didik Pada 
akhirnya kualitas dan hasil belajar semakin membaik, sehingga tidak dilanjutkan dengan siklus berikutnya.

\section{Teknik Analisis Data}

Data yang telah dikumpulkan pada setiap kegiatan observasi dari pelaksanaan siklus penelitian dianalisissecara deskriptif dengan menggunakan teknik presentase untuk melihat kecenderungan yang terjadi dalam kegiatan pembelajaran mata pelajaran IPS.

Dalam pelaksanaan penelitian ini membutuhkan dua siklus perbaikan untuk mata pelajaran matematika. Pada proses perbaikan pembelajaran yang peneliti lakukan adalah melalui tiga tahapan, yaitu diantaranya adalah : perencanaan, pelaksanaan, pengamatan dan refleksi.

Langkah-langkah dalam teknik analisis data yang dilakukan adalah sebagai berikut:

1. Melaksanakan kegiatan pembelajaran, yang terdiri dari kegiatan prasiklus, siklus 1, dan siklus 2 .

2. Mengumpulkan dan menganalisis nilai evaluasi pembelajaran dari tiap siklus.

3. Mendiskripsikan dan membandingkan nilai evaluasi dari tiap siklus.

4. Menentukan tingkat keberhasilan dari hasil evaluasi yang ditempuh dalam proses pembelajaran.

5. Tes, yang digunakan untuk mendapatkan data tentang hasil belajar peserta didik.

\section{HASIL PENELITIAN DAN PEMBAHASAN}

\section{A. Deskripsi Hasil Penelitian Perbaikan Pembelajaran}

Dalam pelaksanaan penelitian, peneliti telah dibantu oleh teman sejawat untuk mengamati pelaksanaan pembelajaran. Peneliti berdiskusi dengan supervisor untuk menemukan kekurangan-kekurangan dalam proses pembelajaran. Selain itu, peneliti telah melakukan refleksi atas pembelajaran yang dilakukan untuk melakukan perbaikan-perbaikan pada pembelajaran selanjutnya. 
Hasil refleksi pada proses pembelajaran yang perlu diperbaiki adalah sebagai berikut:

1. Rendahnya hasil belajar peserta didik pada mata pelajaran IPS.

2. Peserta didik kesulitan dalam menyelesaikan soal-soal latihan.

3. Peserta didik kurang aktif dalam proses pembelajaran mata pelajaran IPS

4. Kurang motivasi peserta didik terhadap mata pelajaran IPS.

\section{Pra Siklus}

Dalam pelaksanaan pembelajaran pra siklus dengan KKM 70 di SD Muhammadiyah 01 Depok kelas 1 Mata Pelajaran IPS tentang "Peristiwa Penting yang Dialami" dari jumlah 31 peserta didik diperoleh hasil rerata peserta didik 55,81 dengan perincin data sebagai berikut jumlah nilai keseluruhan 1640, nilai tertinggi 100, dan nilai terendah 20, 14 orang peserta didik mencapai KKM atau $45.16 \%$ sedangkan yang belum mencapai KKM berjumlah 17 peserta didik atau $54.84 \%$. Sedangkan melalui pengamatan peserta didik yang dapat menjawab pertanyaan guru hanya ada 14 peserta didik, atau sebesar $45.16 \%$ sedangkan yang tidak dapat pertanyaan guru terdapat 17 orang peserta didik atau 54.83\%. Dalam kegiatan pembelajaran pada pra siklus ini sangatlah kurang memuaskan.Hal ini di sebabkan kurangnya minat dan motivasi sehingga peserta didik sulit memahami materi pelajararan IPS.

\section{Siklus 1}

Dalam pelaksanaan pembelajaran siklus 1 di SD Muhammadiyah 01 Depok kelas 1 Mata Pelajaran IPS tentang "Peristiwa Penting yang Dialami” dengan KKM 70 dari jumlah 31 peserta didik diperoleh hasil rerata peserta didik 67,58 dengan perincin sebagai berikut jumlah nilai keseluruhan 2095, nilai tertinggi 100, dan nilai terendah 20, peserta didik mencapai KKM berjumlah 16 atau 51.61\%, sedangkan yang belum mencapai KKM berjumlah 15 peserta didik atau 48.39\%. Melalui data pengamatan peserta didik yang dapat menjawab pertanyaan guru hanya ada 15 orang peserta didik atau $48.39 \%$ sedangkan yang tidak dapat pertanyaan guru terdapat 16 peserta didik atau sebesar $51.61 \%$ 
Dalam kegiatan pembelajaran pada siklus 1 ini sedikit ada peningkatan dalam penilaian hasil belajar hal ini di karenakan menggunakan media dan metode yang digunakan guru tetapi nilai rerata peserta didik belum mencapai KKM hal ini dapat dilihat dari tabel 4.

\section{Siklus 2}

Dalam pelaksanaan pembelajaran siklus 2 di SD Muhammadiyah 01 Depok kelas 1 Mata Pelajaran IPS tentang "Peristiwa Penting yang Dialami” dengan KKM 70 dari jumlah 31 peserta didik diperoleh hasil rerata peserta didik 88,55 dengan perincin sebagai berikut jumlah nilai keseluruhan 2745, nilai tertinggi 100 , dan nilai terendah 65 , peserta didik mencapai KKM berjumlah 29 orang atau $93.5 \%$ sedangkan yang belum mencapai KKM berjumlah 2 peserta didik atau atau $6.5 \%$. Melalui data pengamatan peserta didik yang dapat menjawab pertanyaan guru berjumlah 28 orang peserta didik atau $90.32 \%$ sedangkan yang tidak dapat pertanyaan guru terdapat 3 orang peserta didik atau $9.68 \%$.

Dalam kegiatan pembelajaran pada siklus 2 ini peserta didik sangat berminat dan termotivasi untuk mengikuti pelajaran IPS. Ini di sebabkan karena tersedianya media yang tepat dan sesuai dengan materi yang di ajarkan oleh guru selama proses belajar mengajar berlangsung, sehingga tercipta suasana pembelajaran yang menantang, merangsang dan menyenangkan bagi peserta didik dan pada akhirnya akan berdampak pula bagi meningkatnya hasil prestasi belajar.

Perbandingan perolehan nilai dan ketuntasan belajar pada prasiklus, siklus 1 , dan siklus 2 , terus mengalami peningkatan. Perolehan nilai rerata berturut-turut sebesar 55,81; 67,58; dan 88,55. Tingkat ketuntasan pun menunjukkan peningkatan, pada prasiklus sebesar $45.16 \%$. siklus 1 sebesar $51.61 \%$ dan siklus 2 sebesar $93.5 \%$.

Berikut ini hasil rekapitulasi data nilai dan hasil pengamatan setiap siklus peserta didik pada mata pelajaran IPS di SD Muhammadiyah 01 Depok kelas 1 dalam bentuk tabel. 
Tabel 1

Rekapitulisasi Data Hasil Belajar Pada Pra Siklus, Siklus 1, Siklus 2

\begin{tabular}{|c|c|c|c|c|c|}
\hline No & Nama & $\mathbf{L} / \mathbf{P}$ & Pra Siklus & Siklus 1 & Siklus 2 \\
\hline 1. & Adinda Nurul Fatimah & $\mathrm{P}$ & 20 & 20 & 65 \\
\hline 2. & Ahmad Fauzan Abdilah & $\mathrm{L}$ & 40 & 55 & 75 \\
\hline 3. & Aldy Andika & $\mathrm{L}$ & 40 & 45 & 70 \\
\hline 4. & Audry Cantika & $\mathrm{P}$ & 30 & 45 & 80 \\
\hline 5. & Aulia Qurrota A'Yuna & $\mathrm{P}$ & 100 & 100 & 100 \\
\hline 6. & Audrey Hana Maritzateriza & $\mathrm{P}$ & 20 & 20 & 65 \\
\hline 7. & Danisa Salsa Nabila & $\mathrm{P}$ & 30 & 45 & 100 \\
\hline 8. & Evrida Lutfiani & $\mathrm{P}$ & 70 & 75 & 80 \\
\hline 9. & Fasya Zayid Ramadhan & $\mathrm{L}$ & 40 & 55 & 95 \\
\hline 10. & Fatiha Rizkina & $\mathrm{P}$ & 80 & 100 & 100 \\
\hline 11. & Febbry Atasya Putri & $\mathrm{P}$ & 30 & 50 & 90 \\
\hline 12. & Giattika Putri Permata & $\mathrm{P}$ & 70 & 80 & 100 \\
\hline 13. & Gibran Fauzi & $\mathrm{L}$ & 40 & 70 & 90 \\
\hline 14. & Jidan Saputra & $\mathrm{L}$ & 60 & 75 & 85 \\
\hline 15. & Karisa Fitri & $\mathrm{P}$ & 80 & 100 & 100 \\
\hline 16. & Khalila Ibtisam Maulia & $\mathrm{P}$ & 30 & 45 & 80 \\
\hline 17. & Muhamad Alpin Kurniawan & $\mathrm{L}$ & 40 & 55 & 80 \\
\hline 18. & Melviani Lutfiah & $\mathrm{P}$ & 70 & 80 & 100 \\
\hline 19. & $\begin{array}{l}\text { Michaella Resina Aulia } \\
\text { Rahmadany }\end{array}$ & $\mathrm{P}$ & 80 & 90 & 100 \\
\hline 20. & Miftahunnisya & $\mathrm{P}$ & 100 & 100 & 100 \\
\hline 21. & Muhamad Aldino Sebayang & $\mathrm{L}$ & 50 & 60 & 80 \\
\hline 22. & Muhamad Fais Pratama & $\mathrm{L}$ & 80 & 100 & 100 \\
\hline 23. & $\begin{array}{l}\text { Muhammad Arga } \\
\text { Syawaludin }\end{array}$ & $\mathrm{L}$ & 40 & 55 & 80 \\
\hline 24. & Nabilah Nuraizah & $\mathrm{P}$ & 30 & 40 & 75 \\
\hline 25. & Nasya Aulia Anggraeni & $\mathrm{P}$ & 30 & 45 & 75 \\
\hline 26. & Nizar Mukhafidin & $\mathrm{L}$ & 70 & 75 & 100 \\
\hline 27. & Fadil Dwi Gulam & $\mathrm{L}$ & 80 & 95 & 100 \\
\hline 28. & Raihan Al Shabah & $\mathrm{L}$ & 50 & 60 & 80 \\
\hline 29. & Reyya Dewi Putri & $\mathrm{P}$ & 70 & 80 & 100 \\
\hline 30. & Siti Anjani & $\mathrm{P}$ & 80 & 90 & 100 \\
\hline 31. & Zahra Tulsifa & $\mathrm{P}$ & 80 & 90 & 100 \\
\hline \multicolumn{3}{|c|}{ Jumlah Nilai } & 1640 & 2095 & 2745 \\
\hline \multicolumn{3}{|c|}{ Nilai tertinggi } & 100 & 100 & 100 \\
\hline \multicolumn{3}{|c|}{ Nilai terendah } & 20 & 20 & 65 \\
\hline \multicolumn{3}{|c|}{ Nilai Rata - rata } & 55,81 & 67,58 & 88,55 \\
\hline \multicolumn{3}{|c|}{ Tuntas } & $\begin{array}{c}14 \\
(45.16 \%) \\
\end{array}$ & $16(51.61 \%)$ & $28(93.5 \%)$ \\
\hline \multicolumn{3}{|c|}{ Tidak Tuntas } & $\begin{array}{c}17 \\
(54.84 \%)\end{array}$ & $15(48.39 \%)$ & $2(6.5 \%)$ \\
\hline
\end{tabular}


Tabel 2

Data Rekapitulisasi Pengamatan Hasil Belajar Pra Siklus, Siklus 1, Siklus 2

\begin{tabular}{|c|c|c|c|c|c|c|c|c|}
\hline \multirow{2}{*}{ No } & \multirow{2}{*}{ NAMA } & & \multicolumn{2}{|c|}{ Prasiklus } & \multicolumn{2}{|c|}{ Siklus 1} & \multicolumn{2}{|c|}{ Siklus 2} \\
\hline & & & M & $\mathrm{TM}$ & M & $\mathrm{TM}$ & M & TM \\
\hline 1 & Adinda Nurul Fatimah & $\mathrm{P}$ & & $\sqrt{ }$ & & $\sqrt{ }$ & & $\sqrt{ }$ \\
\hline 2 & Ahmad Fauzan Abdilah & $\mathrm{L}$ & & $\sqrt{ }$ & & $\sqrt{ }$ & $\sqrt{ }$ & \\
\hline 3 & Aldy Andika & $\mathrm{L}$ & $\sqrt{ }$ & & $\sqrt{ }$ & & $\sqrt{ }$ & \\
\hline 4 & Audry Cantika & $\mathrm{P}$ & $\sqrt{ }$ & & $\sqrt{ }$ & & $\sqrt{ }$ & \\
\hline 5 & Aulia Qurrota A'Yuna & $\mathrm{P}$ & & $\sqrt{ }$ & $\sqrt{ }$ & & $\sqrt{ }$ & \\
\hline 6 & Audrey Hana Maritzateriza & $\mathrm{P}$ & $\sqrt{ }$ & & $\sqrt{ }$ & & $\sqrt{ }$ & \\
\hline 7 & Danisa Salsa Nabila & $\mathrm{P}$ & & $\sqrt{ }$ & & $\sqrt{ }$ & $\sqrt{ }$ & \\
\hline 8 & Evrida Lutfiani & $\mathrm{P}$ & & $\sqrt{ }$ & & $\sqrt{ }$ & $\sqrt{ }$ & \\
\hline 9 & Fasya Zayid Ramadhan & $\mathrm{L}$ & & $\sqrt{ }$ & $\sqrt{ }$ & & $\sqrt{ }$ & \\
\hline 10 & Fatiha Rizkina & $\mathrm{P}$ & & $\sqrt{ }$ & $\sqrt{ }$ & $\sqrt{ }$ & $\sqrt{ }$ & \\
\hline 11 & Febbry Atasya Putri & $\mathrm{P}$ & $\sqrt{ }$ & & $\sqrt{ }$ & & $\sqrt{ }$ & \\
\hline 12 & Giattika Putri Permata & $\mathrm{P}$ & & $\sqrt{ }$ & & $\sqrt{ }$ & & $\sqrt{ }$ \\
\hline 13 & Gibran Fauzi & $\mathrm{L}$ & & $\sqrt{ }$ & & $\sqrt{ }$ & $\sqrt{ }$ & \\
\hline 14 & Jidan Saputra & $\mathrm{L}$ & $\sqrt{ }$ & & $\sqrt{ }$ & & $\sqrt{ }$ & \\
\hline 15 & Karisa Fitri & $\mathrm{P}$ & $\sqrt{ }$ & & $\sqrt{ }$ & & $\sqrt{ }$ & \\
\hline 16 & Khalila Ibtisam Maulia & $\mathrm{P}$ & $\sqrt{ }$ & & & $\sqrt{ }$ & & $\sqrt{ }$ \\
\hline 17 & Muhamad Alpin Kurniawan & $\mathrm{L}$ & $\sqrt{ }$ & & $\sqrt{ }$ & & $\sqrt{ }$ & \\
\hline 18 & Melviani Lutfiah & $\mathrm{P}$ & $\sqrt{ }$ & & $\sqrt{ }$ & & $\sqrt{ }$ & \\
\hline 19 & $\begin{array}{l}\text { Michaella Resina Aulia } \\
\text { Rahmadany }\end{array}$ & $\mathrm{P}$ & & $\sqrt{ }$ & $\sqrt{ }$ & & $\sqrt{ }$ & \\
\hline 20 & Miftahunnisya & $\mathrm{P}$ & & $\sqrt{ }$ & & $\sqrt{ }$ & $\sqrt{ }$ & \\
\hline 21 & Muhamad Aldino Sebayang & $\mathrm{L}$ & $\sqrt{ }$ & & $\sqrt{ }$ & & $\sqrt{ }$ & \\
\hline 22 & Muhamad Fais Pratama & $\mathrm{L}$ & & $\sqrt{ }$ & & $\sqrt{ }$ & $\sqrt{ }$ & \\
\hline 23 & Muhammad Arga Syawaludin & $\mathrm{L}$ & & $\sqrt{ }$ & $\sqrt{ }$ & $\sqrt{ }$ & $\sqrt{ }$ & \\
\hline 24 & Nabilah Nuraizah & $\mathrm{P}$ & & $\sqrt{ }$ & $\sqrt{ }$ & $\sqrt{ }$ & $\sqrt{ }$ & \\
\hline 25 & Nasya Aulia Anggraeni & $\mathrm{P}$ & & $\sqrt{ }$ & & $\sqrt{ }$ & $\sqrt{ }$ & \\
\hline 26 & Nizar Mukhafidin & $\mathrm{L}$ & & $\sqrt{ }$ & & $\sqrt{ }$ & $\sqrt{ }$ & \\
\hline 27 & Fadil Dwi Gulam & $\mathrm{L}$ & $\sqrt{ }$ & & $\sqrt{ }$ & & $\sqrt{ }$ & \\
\hline 28 & Raihan Al Shabah & $\mathrm{L}$ & $\sqrt{ }$ & & $\sqrt{ }$ & & $\sqrt{ }$ & \\
\hline 29 & Reyya Dewi Putri & $\mathrm{P}$ & $\sqrt{ }$ & & $\sqrt{ }$ & $\sqrt{ }$ & $\sqrt{ }$ & \\
\hline 30 & Siti Anjani & $\mathrm{P}$ & $\sqrt{ }$ & & $\sqrt{ }$ & & $\sqrt{ }$ & \\
\hline 31 & Zahra Tulsifa & $\mathrm{P}$ & & $\sqrt{ }$ & & $\sqrt{ }$ & $\sqrt{ }$ & \\
\hline \multicolumn{3}{|c|}{ Jumlah } & 14 & 17 & 15 & 16 & 28 & 3 \\
\hline \multicolumn{3}{|c|}{ Prosentase } & $45.16 \%$ & $54.83 \%$ & $48.39 \%$ & $51.61 \%$ & $90.32 \%$ & $9,68 \%$ \\
\hline
\end{tabular}

\section{B. Pembahasan Hasil Penelitian Perbaikan Pembelajaran}

Dalam pelaksanaan pembelajaran pra siklus dengan KKM 70 di SD Muhammadiyah 01 Depok kelas 1 Mata Pelajaran IPS tentang "Peristiwa Penting yang Dialami” dari jumlah 31 peserta didik diperoleh hasil rerata peserta didik 55,81 dengan perincin data sebagai berikut jumlah nilai 
keseluruhan 1640, nilai tertinggi 100, dan nilai terendah 20, 14 orang peserta didik mencapai KKM atau $45.16 \%$ sedangkan yang belum mencapai KKM berjumlah 17 peserta didik atau $54.84 \%$. Sedangkan mlalui pengamatan peserta didik yang dapat menjawab pertanyaan guru hanya ada 14 peserta didik, atau sebesar $45.16 \%$ sedangkan yang tidak dapat pertanyaan guru terdapat 17 orang peserta didik atau $54.83 \%$. Dalam kegiatan pembelajaran pada pra siklus ini sangatlah kurang memuaskan.

Pada pelaksanaan pembelajaran siklus 1 di SD Muhammadiyah 01 Depok kelas 1 Mata Pelajaran IPS tentang "Peristiwa Penting yang Dialami" dengan KKM 70 dari jumlah 31 peserta didik diperoleh hasil rerata peserta didik 67,58 dengan perincin sebagai berikut jumlah nilai keseluruhan 2095, nilai tertinggi 100 , dan nilai terendah 20, peserta didik mencapai KKM berjumlah 16 atau 51.61\%, sedangkan yang belum mencapai KKM berjumlah 15 peserta didik atau 48.39\%. Melalui data pengamatan peserta didik yang dapat menjawab pertanyaan guru hanya ada 15 orang peserta didik atau $48.39 \%$ sedangkan yang tidak dapat pertanyaan guru terdapat 16 peserta didik atau sebesar $51.61 \%$. Walaupun ada ada peningkatan tetapi Walaupun ada ada peningkatan tetapi rerata peserta didik belum sesai KKM

Penyebab rendah prestasi belajar peserta didik pada siklus I adalah adalah guru belum melalukan hal berikut ini .

1. Belum menggunakan media pembelajaran yang sesuai secara maksimal sehingga tidak terciptanya suasana pembelajaran yang kondusif, dan menyenangkan bagi peserta didik

2. Belum menggunakan metode pembelajaran dan teknik pembelajaran yang bervariasi dan efektif

3. Kurang memberikan motivasi pada saat pembelajaran berlangsung sehingga peserta didik tidak tertarik pada pelajaran IPA

4. Belum mengadakan reward dan umpan balik secara langsung selama pembelajaran, sehingga peserta didik tidak aktif. 
Dengan demikian maka peneliti melakukan penelitian pada siklus 2 . Untuk mengatasi permasalah di siklus 1 maka peneliti melakukan sebagai berikut :

1. Menggunakan media pembelajaran yang sesuai secara maksimal sehingga tidak terciptanya suasana pembelajaran yang kondusif, dan menyenangkan bagi peserta didik

2. Menggunakan metode pembelajaran dan teknik pembelajaran yang bervariasi dan efektif

3. Memberikan motivasi pada saat pembelajaran berlangsung sehingga peserta didik tidak tertarik pada pelajaran IPA

4. Mengadakan reward dan umpan balik secara langsung selama pembelajaran, sehingga peserta didik tidak aktif.

Dalam pelaksanaan pembelajaran siklus 2 dari jumlah 31 peserta didik diperoleh hasil rerata peserta didik 88,55 dengan perincin sebagai berikut jumlah nilai keseluruhan 2745, nilai tertinggi 100, dan nilai terendah 65 , peserta didik mencapai KKM berjumlah 29 orang atau $93.5 \%$ sedangkan yang belum mencapai KKM berjumlah 2 peserta didik atau atau $6.5 \%$. Melalui data pengamatan peserta didik yang dapat menjawab pertanyaan guru berjumlah 28 orang peserta didik atau $90.32 \%$ sedangkan yang tidak dapat pertanyaan guru terdapat 3 orang peserta didik atau $9.68 \%$.

Dalam kegiatan pembelajaran pada siklus 2 ini peserta didik sangat berminat dan termotivasi untuk mengikuti pelajaran IPS. Ini di sebabkan karena tersedianya media yang tepat dan sesuai dengan materi yang di ajarkan oleh guru selama proses belajar mengajar berlangsung, sehingga tercipta suasana pembelajaran yang menantang, merangsang dan menyenangkan bagi peserta didik

\section{KESIMPULAN DAN SARAN TINDAK LANJUT}

\section{A. Kesimpulan}

Berdasarkan hasil Penelitian Tindakan Kelas (PTK) melalui aktivitas perbaikan pembelajaran yang telah dilaksanakan mulai dari prasiklus, siklus I 
sampai dengan siklus II pada mata pelajaran IPA, penulis dapat menarik kesimpulan sebagai berikut :

1. Dalam pelaksanaan pembelajaran prasiklus dengan KKM 70 di SD Muhammadiyah 01 Depok kelas 1 Mata Pelajaran IPS tentang "Peristiwa Penting yang di Alami” dari jumlah 31 peserta didik diperoleh hasil rerata peserta didik 55,81 dan peserta didik yang mencapai KKM 14 atau $45.16 \%$ Sedangkan melalui pengamatan peserta didik yang dapat menjawab pertanyaan guru hanya ada $14(45.16 \%)$. Siklus 1 hasil rerata peserta didik 67,58 yang belum mencapai KKM berjumlah 15 peserta didik atau 48.39\%. Melalui data pengamatan peserta didik yang dapat menjawab pertanyaan guru hanya ada 15 (48.39\%) Dalam pelaksanaan pembelajaran siklus 2 diperoleh hasil rerata peserta didik 88,55 peserta didik yang mencapai KKM berjumlah 29 orang atau 93.5\% sedangkan data pengamatan peserta didik yang dapat menjawab pertanyaan guru berjumlah 28 orang peserta didik atau $90.32 \%$

2. Dengan demikian penerapan metode demonstrasi melalui Media Gambar telah memberikan pengaruh yang sangat baik dengan meningkatkan prestasi belajar dan motivasi peserta didik materi yang disampaikan dimengerti peserta didik, Tanggung jawab peserta didik terhadap tugas tinggi, serta membantu peserta didik untuk terlibat aktif di dalam kelas dan

\section{B. Saran Tindak Lanjut}

Berdasarkan pada kesimpulan diatas ada beberapa hal yang sebaiknya dilakukan guru dalam upaya meningkatkan hasil belajar peserta didik.

1. Motivasi yang kuat sangat dibutuhkan oleh seorang peserta didik sebelum melakukan pembelajaran.

2. Suasana belajar yang aktif di dalam kelas akan memotivasi peserta didik dalam belajar.

3. Penggunaan metode demonstrasi melalui Media Gambar dapat membantu peserta didik untuk lebih cepat memahami konsep materi 
pelajaran. Dalam hal ini metode demonstrasi dapat menjadi alternatif yang digunakan guru dalam mengajarkan pembelajaran IPS.

4. Memberikan kesempatan kepada peserta didik untuk lebih aktif di kelas, mengeluarkan pendapat untuk menumbuhkan rasa percaya diri serta keberanian anak dalam menjawab pertanyaan

\section{DAFTAR PUSTAKA}

Arsyad, Arsyad, \& Sulfemi, Wahyu Bagja. (2013). Pengaruh Persepsi Guru Tentang Kemampuan Manajerial Kepala Sekolah dan Kecerdasan Emosional Guru Terhadap Kinerja Guru (Studi Kasus Di SMK Muhammadiyah 6 Kabupaten Bogor). Fascho 2 (1), 1-9.

Arsyad, Arsyad dan Sulfemi, Wahyu Bagja. (2018) Metode Role Playing Berbantu Media Audio Visual Pendidikan dalam Meningkatkan Belajar IPS. Jurnal Pendidikan Ilmu Pengetahuan Sosial Indonesia. 3 (2). 41 46

Anitah W, Sri dkk, 2014, Strategi Pembelajaran di SD, Tanggerang Selatan : Universitas Terbuka

Ahmadi, Abu. (2009). Ilmu Sosial Dasar . Jakarta Rineka : Cipta

Asrori, Muhammad, 2009, Penelitian Tindakan Kelas, Bandung : CV Wacana Prima

Barber, Bart dan Shermis, (1977). Publik Talk and Civiv Action : Education for Participation in a Strong Demokracy in Rauner. CIVNet

Djamarah, (2000), Strategi belajar mengajar, Jakarta:Rineka Cipta

Fajartriani, Tia dan Sulfemi, Wahyu Bagja. (2014). Pengaruh Motivasi Kerja Guru dan Iklim Organisasi Terhadap Kinerja Guru SMA Negeri di Kecamatan Cigudeg. Edutecno. 8 (1), 17-26.

Jihad Asep, Abdul Haris. (2013). Evaluasi Pembelajaran. Yogyakarta: Multi Pressindo

Hamalik, Umar. (2008). Kurikulum dan Pembelajaran. Jakarta : PT Bumi Aksara.

Sumantri, M. Dan Syaodih, N (2006). Perkembangan Peserta Didik. Jakarta: Universitas Terbuka

Puskur. (2001). Kurikulwn Berbasis Kompetensi, Mata Pelajaran Sains Sekolah. Dasar. Jakarta

Sapriya. (2009). Pendidikan IPS. Bandung: PT Remaja Rosda Karya. 
Slameto. (2003), Belajar dan Fakta yang Mempengaruhinya. Jakarta : Rineka Cipta

Sudirman, Sudirman \& Sulfemi, Wahyu Bagja. (2010). Korelasi Antara Konsep Diri Guru dengan Profesionalisme Guru di SMA Negeri 1 Pamijahan Kabupaten Bogor. Edutecno 2 (2), 10-19

Sugiri, Sugiri \& Sulfemi, Wahyu Bagja. (2011). Pendidikan Multi Kultur di Sekolah Berbasis Keagamaan. Edutecno. 3 (2), 11-20.

Supardi, (2012), Penelitian Tindakan Kelas, Jakarta : Bumi Aksara

Syah, Muhibbin. (2004), Psikologi Pendidikan dengan Pendekatan Baru. Bandung : Remaja Rosdakarya.

Sardiyo, dkk. (2009). Pendidikan IPS di SD. Tanggerang Selatan : UniversitasTerbuka

Sagala, Syaiful. (2008). Konsep dan Makna Pembelajaran. Jakarta : Alfabeta.

Sabri, Alisuf. (1995). Psikologi Pendidikan. Jakarta : Pedoman Ilmu Jaya.

Sulfemi, Wahyu Bagja. (2009). Modul Pembelajaran Pendidikan Pancasila dan Kewarganegaraar. Bogor : STKIP Muhammadiyah Bogor

Sulfemi, Wahyu Bagja. (2015). Kemampuan Pedagogik Guru. Prosiding Seminar Nasional. STKIP Muhammadiyah Bogor 1. (1). 71-8.

Sulfemi, Wahyu Bagja. (2016). Kompetensi Profesionalisme Guru Indonesia dalam Menghadapi MEA. Prosiding Seminar Nasional STKIP Muhammadiyah Bogor. 1 (1), 62-77.

Sulfemi, Wahyu Bagja dan Abdul Qodir. (2017). Hubungan Kurikulum 2013 Dengan Motivasi Belajar Peserta Didik Di SMK Pelita Ciampea. Edutecno 17 (2), 1-8

Sulfemi, Wahyu Bagja dan Lestari, Ayu Hopilatul. (2017). Korelasi Kompetensi Pedagogik Guru dengan Prestasi Belajar Mata Pelajaran IPS Di SMP Muhammadiyah Pamijahan Kabupaten Bogor. Edutecno. 16 (1), 1-16.

Sulfemi, Wahyu Bagja dan Supriyadi, Dede. (2018). Pengaruh Kemampuan Pedagogik Guru dengan Hasil Belajar IPS. Edutecno 17 (1), 1-10.

Sulfemi, Wahyu Bagja. (2018). Hubungan Motivasi Belajar Dengan Hasil Belajar IPS Di SMP Kabupaten Bogor. Edutecno 18(2), 1-8.

Sulfemi, Wahyu Bagja dan Nurhasanah. (2018). Penggunaan Metode Demontrasi dan Media Audio Visual Dalam Meningkatkan Hasil Belajar Peserta Didik Mata Pelajaran IPS. Jurnal Pendas Mahakam. 3 (2). 151-158.

Sulfemi, Wahyu Bagja dan Hilga Minati. (2018). Meningkatkan Hasil Belajar Peserta Didik Kelas 3 SD Menggunakan Model Picture And Picture dan Media Gambar Seri. JPSD. 4 (2), 228- 242 
Sulfemi, Wahyu Bagja dan Setianingsih. (2018), Penggunaan Tames Games Tournament (TGT) Dengan Media Kartu Dalam Meningkatkan Hasil Belajar. Journal of Komodo Science Education (JKSE. 1 (1), 1-14

Sulfemi, Wahyu Bagja. (2018). Pengaruh Disiplin Ibadah Sholat, Lingkungan Sekolah, dan Intelegensi Terhadap Hasil Belajar Peserta Didik Mata Pelajaran Pendidikan Agama Islam. Edukasi: Jurnal Penelitian Pendidikan Agama dan Keagamaan. 16 (2), 166-178

Sulfemi, Wahyu Bagja dan Desmiati, Zulaicha. (2018). Model Pembelajaran Missouri Mathematics Project Berbantu Media Relief Experience dalam Meningkatkan Hasil Belajar Siswa. Jurnal Pendas Mahakam . 3 (3), 232245 .

Sulfemi, Wahyu Bagja. (2018). Manajemen Kurikulum di Sekolah. Bogor : Visi Nusantara Maju.

Sulfemi, Wahyu Bagja., \& Yuliana, Desi. (2019). Penerapan Model Pembelajaran Discovery Learning Meningkatkan Motivasi dan Hasil Belajar Pendidikan Kewarganegaraan. Jurnal Rontal Keilmuan Pancasila dan Kewarganegaraan. 5 (1), 17-30.

Sulfemi, Wahyu Bagja. (2019). Model Pembelajaran Kooperatif Mind Mapping Berbantu Audio Visual Dalam Meningkatkan Minat, Motivasi dan Hasil Belajar IPS. Jurnal Pendidikan Ilmu Pengetahuan Sosial Indonesia (PIPSI). 4 (1), $13-19$

Sulfemi, W. B. (2019). Modul Pembelajaran Perundang-Undangan Pendidikan. Bogor : STKIP Muhammadiyah Bogor

Winkel, W.S. (1996). Psikologi Pengajaran, Edisi yang Disempurnakan, Cetakan ke-4 Jakarta :Grasindo.

Winaputra, Udin S. Dkk. (2010). Materi dan Pembelajarn IPS SD. Jakarta : Universitas Terbuka

Wahab, Abdul Azis (2008). Konsep Dasar IPS. Jakarta : Universitas Terbuka

Wardhani, IGAK, (2014), Penelitian Tindakan Kelas, Tangerang Selatan : Universitas Terbuka

Yusfiriadi, Yusfiriadi, \& Sulfemi, Wahyu Bagja. (2011). Pemberdayaan Unit Produksi Melalui Pendekatan Manajemen Stratejik di SMK Pertiwi Kabupaten Bogor. Edutecno. 3 (1), 1-10.

Yusfiriadi, Yusfiriadi, \& Sulfemi, Wahyu Bagja. (2012). Penyelewangan Dana Dalam Dunia Pendidikan. Fascho 1 (1), 1-9. 